\title{
Implementation of Spatial and Development Planning in East Kalimantan Province
}

\author{
Wedo Aru Yudhantoro ${ }^{1}$, Arty Dwi Januari ${ }^{1}$, Atiti Setyaning Utami M. ${ }^{1}$, Erline Fitridiah Pitaloka ${ }^{1}$, \\ Kunny Izza Indah A. ${ }^{1}$, Nurul Rusdayanti ${ }^{1}$, Poerborini Damayanti, Sindhung Wardana ${ }^{1}$, \\ Siti Kardian Pramiati ${ }^{1}$, Siti Shara ${ }^{1}$, Hayati Sari Hasibuan ${ }^{1}$, and Rudy P. Tambunan ${ }^{1}$ \\ \{wedo.aru@ui.ac.id ${ }^{1}, \underline{\text { arty.dwi91@ui.ac.id }}^{1}$, atiti.setyaning@ui.ac.id ${ }^{1}, \underline{\text { erline.fitridiah@ui.ac.id }}^{1}$, \\ kunny.izza@ui.ac.id ${ }^{1}$, nurul.rusdayanti@ui.ac.id ${ }^{1}$, poerborini.damayanti@ui.ac.id ${ }^{1}$, \\ sindhung.wardana@ui.ac.id ${ }^{1}$, siti.kardian@ui.ac.id ${ }^{1}$, siti.shara91@ui.ac.id ${ }^{1}$, \\ hayati.hasibuan@ui.ac.id ${ }^{1}$, rudyptamb@ gmail.com $^{1}$ \}
}

School of Environmental Science, Universitas Indonesia, Jakarta ${ }^{1}$

\begin{abstract}
This study is testing for the truth of development, and correctly implementation from spatial plans document in East Kalimantan, Indonesia. The most significant potential from East Kalimantan is mining products and palm oil products. Qualitative method are used on this research by using analysis process from the real development data from 2016 until 2019 using geospatial analysis process. In mining areal case, the most significant permission already developed in residential areas with number $75,22 \%$, which mean $2.062 .075,5$ hectare areas. The same problem has happened in palm oil areal that develop in 46,7\%, which mean 543.021,92 hectare areas. Another result was showed that in mining and oil palm areas already has overlapping areas in $3,53 \%$ or $449.753,53$ hectare areas. There is a problem in the development process in the past three years. It needs to evaluate in real to make sure the urban landuse plan from 2016 until 2036 still in the right way.
\end{abstract}

Keywords: Development; Spatial planning; Spatial structure; Urban land use

\section{Introduction}

Indonesia national constitution about spatial planning number 26/2007 defined spatial planning as unity of spatial planning processes in a system, spatial use, \& spatial use control. So that spatial planning can be defined as a process for determining the spatial structure and spatial patterns, which include the preparation and determination of spatial plans. Spatial planning based on administrative areas consists of national spatial planning, provincial spatial planning, and district/city spatial planning. The spatial planning was realized in the National, Provincial, and Regency / City Spatial and Regional Spatial Plans, and there are also Spatial Detail Plans covering the Sub-district area. Spatial planning is needed to overcome competition and conflict between various uses in a limited area. The effort to realize the spatial structure and spatial pattern following the spatial plan through the preparation and implementation of the program and its financing is called the use of space. Spatial utilization is carried out through the implementation of the spatial use program and its financing contained in the regional spatial plan. Spatial utilization refers to the spatial functions stipulated in the spatial plan carried out by developing land stewardship, water stewardship, air stewardship, and stewardship of other natural resources. Government and regional goverments has fully priority to consider who can manage the stewardship land that has rights commitment to sure the land rights in the function. In the space of the land for protected 
function rooms, the Government and the regional government give priority first to accepting the rights transfer of land from some holder who has already relinquishes the rights.

East Kalimantan Province, which has an area and land area of around 12,726,752 ha, which consists of a land area of 12,533,681 ha and inland waters covering 193,071 ha, also has the right to organize and utilize its own territorial space. As the third-largest province, East Kalimantan Province has abundant natural resource potential, where most of the potential has not used optimally. Most of the natural resources and their products exported abroad, so that this province is one of the leading foreign exchange earner provinces for the country, particularly from the mining, forestry and other yield sectors. Data related to the extent of plantation land in regencies and cities throughout East Kalimantan is still not synchronous with the provincial spatial plan. It was confirmed by East Kalimantan Governor H Awang Faroek Ishak at the East Kalimantan Plantation Development and Floating Evaluation Meeting in the Edge Meeting Room 1. One example, the area of land designated for plantations within the provincial spatial planning for Berau was around 425,645 hectares while the realization was only 126 thousand hectares. Also, the Regency of Kutim of the total area of land owned and contained in the provincial spatial structure is around 881 thousand hectares, but the realization has only reached 429 thousand hectares. Besides, there are indications that the plantation lands have already taken over the function of land carried out with the permission of the local area so that overlapping land occurs due to different or changing land use.

To achieve the objectives of the strategy, the provincial government realized that they needed a commitment from many interests, like stakeholders. Green Growth Compact (GGC) concept has taken by Governor of East Kalimantan in September 2016 as a tool for bring together initiatives that come from some interests, like private sector, local \& national government, communities, NGOs, until universities sector for research. During the 2017 Governor of the Climate and Forests Task Force (GCF) meeting already held in 2017 that contained 7 GGC pilot initiatives that help for develop the goals of the East Kalimantan development. However, in its implementation, there is a mismatch of the actual conditions with the target to be achieved. Deforestation rates in East Kalimantan from 2000 - 2015 are around 60,000 ha per year, more comprehensive than the city of Balikpapan, and 30 percent of those deforestations occur in forest areas.

This research used qualitative methods that needed analysis by the geospatial analysis process by using an application. The documents used in this research are spatial planning documents of East Borneo, mapping data from the Ministry of Villages, disadvantaged regions, and transmigration of the Republic of Indonesia. Another process to get the data is by literature review and compare it with the actual data. The location of the research is in East Borneo with a subject area of the research in mining subject area, agriculture area, settlement area, forest area, and land-use area. The population of the research consists of area mapping of East Borneo with the time of research basic from secondary data of spatial development planning in 2016 until the reality in 2019.

The result data from the interpretation process in real will have to compare with the public land-use planning data. After that, we will see how much the overlapping has happened already. For the next will gift some recommendations for being part of solving the problems or fixing the problems. The necessary procedure is to collect the data of East Kalimantan Province from actually of development from 2016 to 2019, combine and compare the real data with the urban land-use planning regulation of East Kalimantan Province. The next process is to collect the national regulation, region regulation, and combine it again with the real data after do combining it before. Moreover, after this, we will look for the best recommendation to solve the problems. 


\section{Geographic Condition}

East Kalimantan Province is the second largest provinces in Indonesia Republic after Papua, having abundant natural resource potential where most of the potential has not used optimally. The natural resources and their products already exported abroad, so this Province is the primary foreign exchange earner for the country, especially from the Mining, Forestry, and other yield sectors. The province of East Kalimantan are located on the most east island of Borneo and is also a border region with Malaysia, especially Sabah and Sarawak. East Kalimantan is a province in Indonesia located between $113^{\circ} 35^{\prime} 31^{\prime \prime}$ to $119^{\circ} 12^{\prime} 48^{\prime \prime}$ east longitude, and between $2^{\circ} 34^{\prime} 23^{\prime \prime}$ north latitude to $2^{\circ} 44^{\prime} 14^{\prime \prime}$ south latitude with an area of $127,346.92 \mathrm{~km}^{2}$ [3]. The province was beside with Malaysia in the north and some island of Indonesia like Sumatra, Sulawesi, and Java Island [1]. Based on Local Regulation of Kalimantan Number 1 of 2016 about Urban Land-use Planning of East Borneo Province from 2016 - 2036, Ease Borneo has potential land in $12.638 .931 \mathrm{Ha}(75,54 \%)$ from all the area of East Borneo Province.

Table 1. Data Administrative of East Kalimantan Province in 2016

\begin{tabular}{llll}
\hline Regencies/City & Areal (Ha) & $\begin{array}{c}\text { Number of sub- } \\
\text { district }\end{array}$ & $\begin{array}{c}\text { Number of } \\
\text { villages }\end{array}$ \\
\hline Paser & 1.109 .696 & 10 & 144 \\
Kutai Barat & 1.370 .92 & 16 & 194 \\
$\begin{array}{l}\text { Mahakam Ulu } \\
\text { Kutai }\end{array}$ & 1.994 .941 & 5 & 50 \\
Kertanegara & 2.598 .808 & 18 & 237 \\
Kutai Timur & 3.105 .171 & 18 & 135 \\
Berau & 2.173 .519 & 13 & 110 \\
Penajam Paser & 292.373 & 4 & 54 \\
Utara & & & \\
Balikpapan & 51.225 & 6 & 34 \\
Samarinda & 71.653 & 10 & 59 \\
Bontang & 16.314 & 3 & 15 \\
Kalimantan & 12.734 .692 & 103 & 1.032 \\
Timur & & & \\
\hline
\end{tabular}

Source: Urban land-use plan of East Kalimantan in 2016

Based on the slope of the land and the altitude, the topographic characteristics of the Province of East Kalimantan are dominated by lands with slopes above 40 percent and elevations of less than 500 meters above sea level. Flatland (0-2\%) in East Kalimantan Province is generally only found in coastal areas and large river basins, which cover about 10.70 percent of the total area. While the land has a sloping level (2-15\%) reaches 16.16 percent. The rest is hilly land with a slope level of $>15 \%$, with an area of around $73.14 \%$ of the total area of East Kalimantan Province. Food crop development is only possible in flat to sloping areas or areas with a slope of 0-15 percent, whereas the land with a higher slope level (> 15 percent) is only suitable for annual crops and conservation areas. Soil types in the East Kalimantan mainland area were dominated by latosol red and yellow podsolic soils and lithosols, which spread in the Central and North parts of East Kalimantan. There are 3 (three) major fault patterns in East Kalimantan Province. Among them Mangkalihat Fault, 
Sangkulirang Fault, and Megashear Adang. Moreover, there is also the Samarinda Anticlinorium. Potential minerals found in East Kalimantan are coal, oil and gas, gold, galena, and others. The number of rivers in East Kalimantan Province is 157 large and small rivers, including the Mahakam River, which has a length of $920 \mathrm{~km}$ with an area of $77,913 \mathrm{~km}^{2}$ of the river. There is also has Kelay River with $254 \mathrm{~km}$ length. The number of lakes is 18 (eighteen), with 3 (three) largest lakes being Lake Melintang covering 11,000 hectares, Lake Semayang covering 13,000 hectares, and Lake Jempang covering 15,000 hectares. Besides being used as transportation infrastructure and raw water sources, these rivers can also use as Hydroelectric Power Generation (PLTA) such as the Kelay River, Telen River, and Medang River [4].

\section{Ecosystem Condition}

The condition of the East Kalimantan Ecosystem is one of the mainland landscapes on the island of Kalimantan, which has a very varied geomorphological form. Here some mountains and hills have been famous since colonial times, such as the Meratus Mountains, the Schwaner Mountains, the Muller Mountains, and the Iban Mountains. In these mountains, the highest points in Kalimantan, Indonesia, are. The mountains are also the headwaters of almost all major rivers in Kalimantan. They are called the Heart of Borneo and are known as the Heart of Borneo. Besides, East Kalimantan also has extensive freshwater swampy plains. Kalimantan's major rivers play a significant role in shaping such plains because freshwater swamps are known as the "floodplains" of these rivers. Central Mahakam Swamps (East Kalimantan). The coastal areas of Kalimantan Island are, for the most part, characterized by mangrove swamps that grow on tidal plains. In addition to the morphological forms above, in the middle of the mainland of Kalimantan can also be found a reasonably extensive Karst / Cretaceous area, namely the Sangkulirang - Mangkalihat karst area which stretches across East Kutai Regency and Berau District. Meanwhile, the mainland on the coast of Kalimantan is a place to live for mangrove ecosystems (tidal swamps) and coastal forest ecosystems (non-tidal dry land).

\section{Demographic Condition}

The population of East Kalimantan in 2003 totaled 2,311,162 people. In 2010 based on the results of the population census, it reached 3,047,500 people. Therefore, during this period, the population of East Kalimantan increased by 736,338 people, with an average annual population growth of 3.60 percent. The population of 2013 was 3,300,517 people with the composition of the population according to sex consisting of $1,731,820$ male population $(52.47 \%)$ and $1,568,697$ female population $(47.53 \%)$. Based on the calculation of the Central Statistics Agency (BPS), demographic bonuses in Indonesia will occur between 2020 and 2030, while each province will get demographic bonuses at different times. 


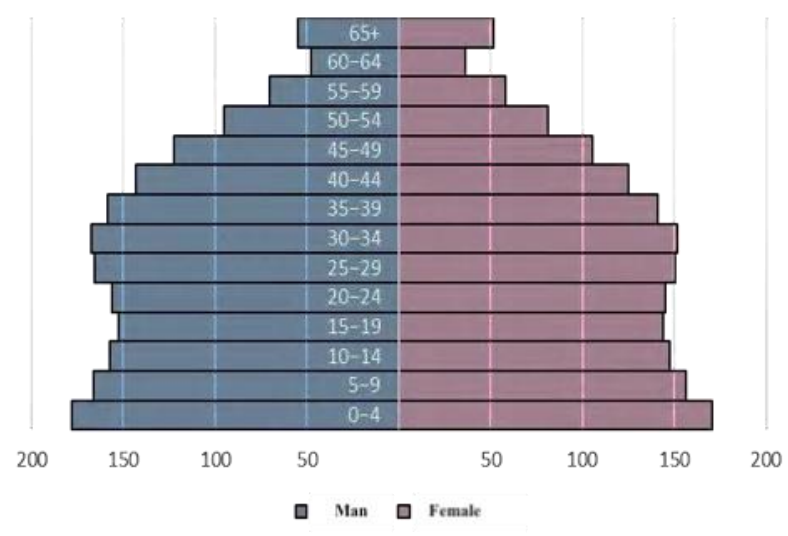

Fig. 1. Number of the Population by Age and Gender in East Borneo Province on 2016

(Source: Central Bureau of Statistics East Kalimantan Province on 2018)

East Kalimantan has received a demographic bonus since 2013. It can see from the population of East Kalimantan's productive age (15-64 years), which has reached precisely 70 percent of the total population. Seventy percent of the productive age population bears 30 percent of the non-productive age population (aged $<15$ years and 65 years and above). At present, the dependency ratio or ratio between unproductive age population and productive age population in East Kalimantan Province has reached 42, which means that every 100 productive population in East Kalimantan bears 42 unproductive population. It can be analogous, a house with four people, three workings, and one were borne. This number is predicted to continue to decline until 2028, and after that, it will increase again and end in 2045. The occurrence of peak productivity is very beneficial in terms of development. The high number of productive age will encourage economic growth. East Kalimantan will potentially benefit in the form of rising gross domestic product (GDP). However, the benefits of a demographic bonus can obtain with a note that there are already job preparation, proper education, and adequate health and nutrition services. If this is not available, some problems will arise. Call it a high unemployment rate, rising crime rates, to the occurrence of social conflict [2].

\section{Economic Condition}

The province's main products are mining products such as oil, natural gas, and coal. Agriculture, tourism, and industries sector are another sector that already developing in East Kalimantan. Some regions, such as Balikpapan and Bontang, have begun to develop industrial estates in various fields to accelerate economic growth. While districts in East Kalimantan are now starting to open up their territories to make plantations such as oil palm and others. Derawan Islands in Berau, Kayan Mentarang National Park, and Batu Lamampu Beach in Nunukan, crocodile farms in Balikpapan, deer farms in Penajam, Dayak Pampang Village in Samarinda, Amal Beach in Tarakan City, Kumala Island in Tenggarong is some example of several attractive tourist destination in East Kalimantan. Asphalts road is one of obstacle in 
East Kalimantan. Many cities of the province still do not have asphalt roads access, so for the accessbility many people travel by using boat and airplane, and it is no wonder that East Kalimantan has many pioneer airports. Also, there will be plans to make the Balikpapan Samarinda - Bontang - Sangata Highway smooth the economy.

East Kalimantan is a mining and timber-producing province which has a significant contribution to Indonesia's economy. Gross Regional Domestic Product (GRDP) values from East Kalimantan province has always increased in each period, although the increase has increasingly seen to slow down until finally generally declines in 2015. However, in 2016, the value of the GRDP of East Kalimantan Province has increased with a magnitude of 507.07 trillion rupiahs, compared to 2015, reaching 503.69 trillion rupiahs. East Kalimantan Province GRDP is a sector related to coal and oil and gas so that if the dominance of the non-renewable resource sector is eliminated, the GRDP of East Kalimantan Province will only reach 241.69 trillion rupiahs.

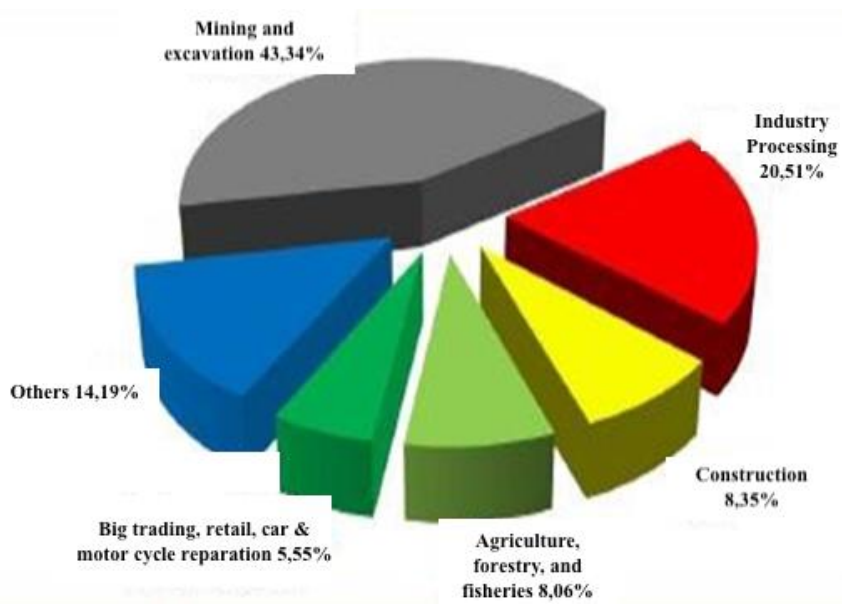

Fig. 2. Economic Growth in East Kalimantan Province by Economic Sector

\section{(Source: Central Bureau Statistics of East Kalimantan Province 2016)}

Formation of the regional economy was dominated by mining and quarrying groups, which reached 43.34 percent. Nevertheless, the dominance of the economic structure of the mining and quarrying category has decreased significantly from year to year, as can be seen from the contribution of the sector and sector growth, which has slowed, even negative growth in 2016 . This East Kalimantan Province will cause economic turmoil in the future if it not accompanied by the sustainable management of the developing economy. An exciting thing related to the economy in East Kalimantan Province is that although economic growth in the Province is far below the national economic growth, the contribution of the Province of East Kalimantan to national income is very high. It is due to the high contribution of the oil and gas sector in the 
formation of the GRDP of East Kalimantan Province, which has an impact on the contribution of the National GRDP. However, what needs to be marked is the production of oil, gas, and coal continues to decline from year to year, which causes the added value to decline so that economic growth also declines, although the GRDP is still relatively high.

\section{Implementation Study of the Urban Land-Use Plan in East Kalimantan Province}

\subsection{Plantation permission in the forest area}

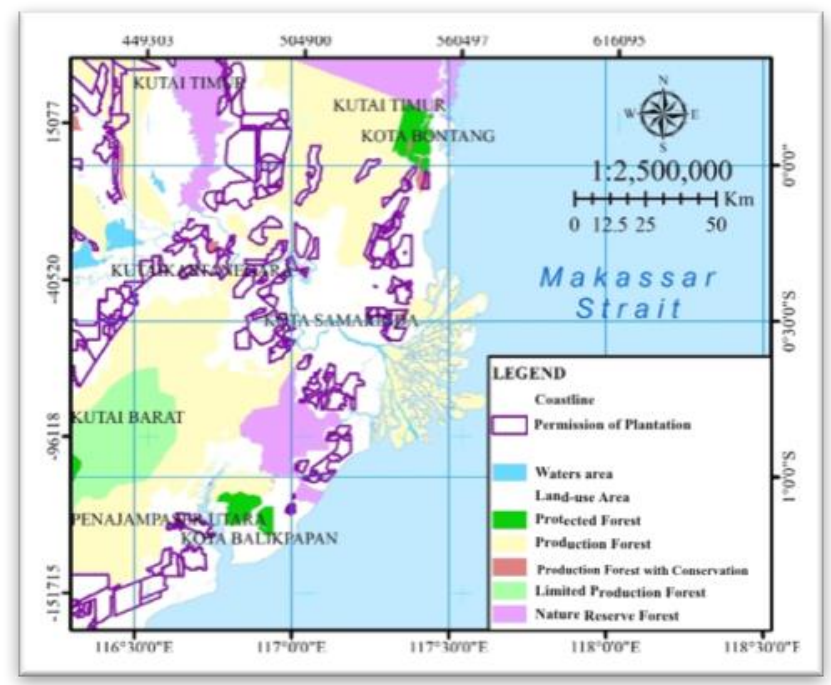

Fig. 3. Map of Permission Plantation in Forest Areal

Based on PP 104/2015, plantation business activities whose licenses are issued by regional governments based on provincial or district/city regional spatial plans stipulated by regional regulations before the enactment of Law Number 26 on 2007 that concern in Spatial Planning and based on prevailing spatial planning are by the previous spatial plan but based on the Forestry Law, the area according to the latest Forest Area map [8]:

(i) is a convertible area for production forest area

(ii) is a permanent area for production forest and limited area for production forest that based on area processed through exchange of forest area

It has one year maximum period since the area entry into force of PP 104/2015 can submit applications for the Release of forest area or exchange of forest area that submitted to Indonesian Minister of Environment and Forestry ("Minister of LHKI"). Release of forest area and Exchange of forest area There are still provisions in the implementation, namely:

(i) Permanent guarantee of Forest Area area of at least $30 \%$ (thirty percent) of the total watershed (DAS), island, and province with proportional distribution. 
(ii) Maintaining the carrying capacity of the Forest areas.

(iii) Exchange of Forest Areas can do with replacement land from: non - Forest Area land and Convertible Production Forest areas.

Based on the results of data processing, it known that the majority of plantation business licenses in the Province of East Kalimantan are in Other Use Areas (OUA), which are $1,085,754.72 \mathrm{Ha}$ or $93.38 \%$. Another area of use is the non-forest area. While plantation business permits in the Production Forest (PROFER) areas are 44,791.95 Ha or 3.85\%, Limited Production Forest (LPF) area is 20,204.02 Ha or $1.74 \%$, and in the Production Forest area can be converted, Protection Forest, Waters, Nature Reserve / Tourism Forest areas of $11,943.61 \mathrm{Ha}$ or as much as $1.03 \%$. Based on PP 104/2015, the plantation business permit of $5.59 \%$ in the area of permanent production Forest areas and limited production forest areas in East Kalimantan region does not necessarily violate the rules. It has been a request for release the forest areas or the exchange forest areas to Indonesian Minister of Environment and Forestry and has fulfilled the conditions of the exchange of forest areas.

\subsection{Mining Permission in Forest Area}

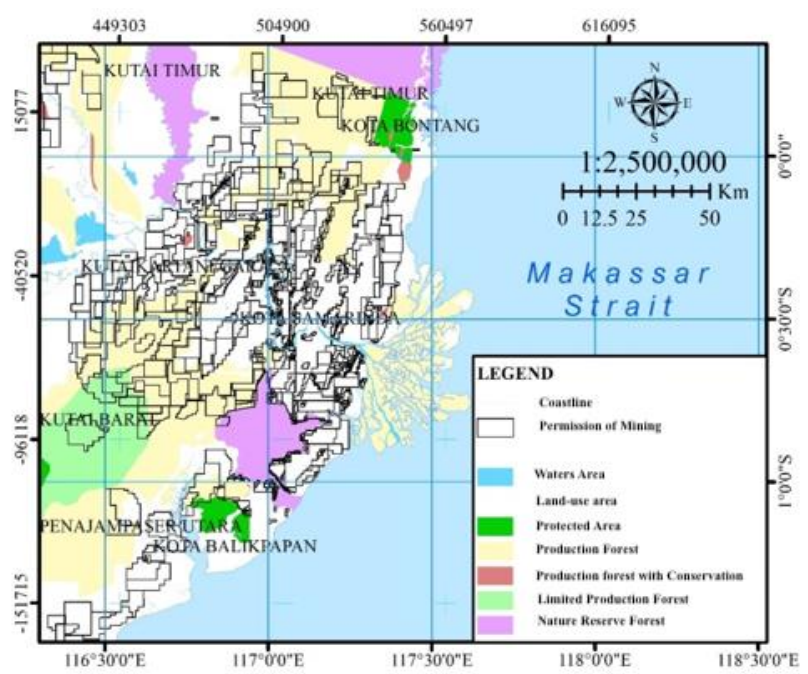

Fig. 4. Map of Mining Permission in Forest Area

The interests of development outside forestry can only be carried out within PF and PROFER areas that are selective without changing the main functions of the forest area. In protected forest areas, mining prohibited using open mining patterns. The use of forest areas for mining purposes is done through the granting of a lease-to-use permit by the Minister by taking into account specific area and time limits and environmental sustainability. Based on the provisions of Article 38 of Law No. 41 of 1999, the Joint Decree between the Minister of Mines and Energy increasingly narrowing that mining activities in forest areas can only be carried out in forests precious protection for oil and gas and open mining in production forests.Based on the results of data processing, it known that the most significant mining business permit in East Kalimantan Province is in the PROFER area of 1,100,518.23 Ha or $38.54 \%$ and followed in OUA areas of $1,052,539.85$ or $36.86 \%$. LPF area of $544,686.38$ Ha or 
$19.08 \%$, and in Production Forest areas that can convert, Protected Forests, Waters, Nature / Tourism Reserves covering an area of $157,482.48$ hectares or $5.52 \%$. This percentage of forest use is the percentage of mining business permits in the forest area per overall mining business permit.

Management and handling of licensing systems, especially mining permits, are very complicated because they involve cross sectors. For example, the IUP process in other use areas OUA is issued by the Ministry of Energy and Mineral Resources (MEMR), but if the requested mining area included in a forest area, the IUP holder must take care of IPPKH at the Ministry of Environment and Forestry. The existence of Laws in Indonesia is still sectoral, which is more concerned with the sector because its drafting comes from ministries related to that sector. As a result, the licensing process in each sector, such as forestry, mining, and the environment regulated by a separate law and ministry (Rosadi, 2008). The conclusion is that although a mining activity permit has obtained, it has not yet been granted a borrowing-use permit from the forestry mining business that cannot carry out as long as the working area is in a forest area.

\subsection{Plantation Permission in Land-use Area}

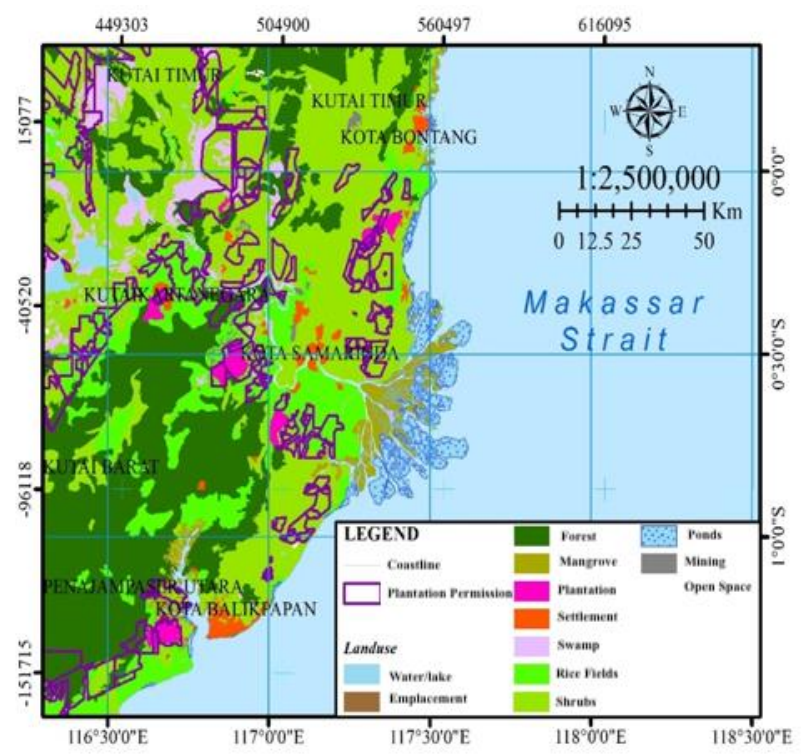

Fig. 5. Map of Plantation Permission for Land-use

Based on the results of data processing, the most substantial plantation business permit lies in the use of shrubland with an area of $370,324.10$ hectares or $31.85 \%$. Then followed by the use of secondary dryland forest land area of $280,981.37 \mathrm{Ha}$ or $24.17 \%$, dryland agriculture mixed with bush $11115.52 \mathrm{Ha}$ or $13.86 \%$ area, bush/swamp shrubland area of $131.526 .87 \mathrm{Ha}$ or $11,31 \%$. (Secondary Swamp Forests, Swamps, Plantation Forests, Dry Land Agriculture, Settlements, Secondary Mangrove Forests, Open Land, Mining, Primary Dry Land Forests, Ponds, Primary Swamp Forests, Rice Fields) of 115,059.21 Ha or 9.90\%. Whereas plantation business licenses that have completed are in the use of plantation land, which is $103,687.23$ Ha or $103,687.23 \mathrm{Ha}$ or $8.92 \%$. The government has planned land use in its territory, but it 
appears that between the land use planning and the actual location of the permit given is very much different.

\subsection{Mining Permission in Land-use Area}

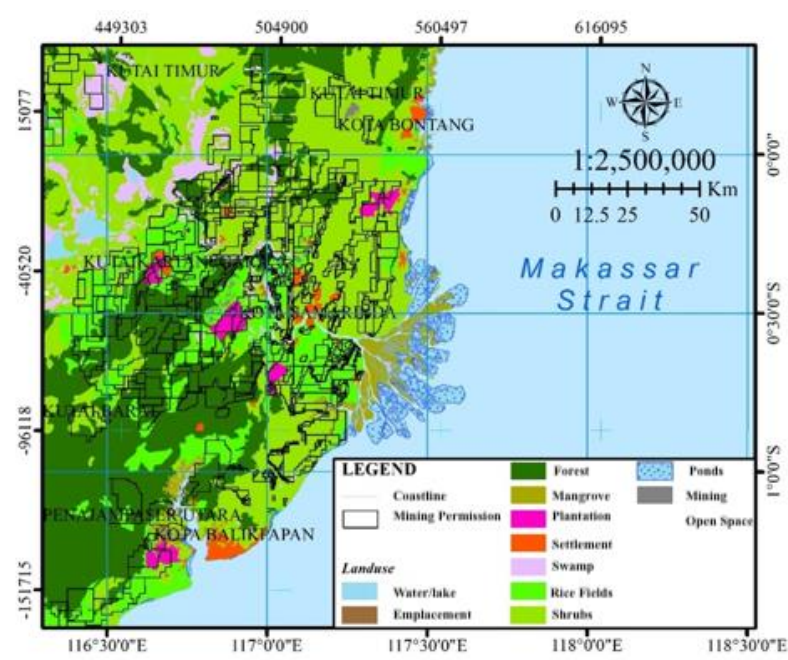

Fig. 6. Map of Mining Permission in Land-use Area

Based on the results of data processing, the most substantial mining business permit is in the use of Secondary Dry Land Forest land, which is $1,084,739.46 \mathrm{Ha}$ or $37.99 \%$. Then followed by the use of $843,824.43 \mathrm{Ha}$ of Shrubland, or $29.55 \%$, others (Secondary Swamp Land, Swamp, Crop Land, Dry Land Agriculture, Settlement, Secondary Mangrove Forests, Open Land, Mining, Dry Land Htn Primary, Tambak, rice fields) with an area of 443,974.23 Ha or 15.55\%, Agriculture of Mixed Mixed Land of Shrubland 325,717.24 Ha or 11.41\%, and Swamp / Shrub area of $156,971.58 \mathrm{Ha}$ or at $5.50 \%$. As explained in the chapter on the granting of permits over land areas, the granting of a mining business permit is given by the Government, where the granting of the permit regulated in Law number 4 of 2009 about Mineral and Coal Mining Law. Granting of the permit will previously carry out a technical feasibility study, an economic feasibility study, and the preparation of environmental documents. When viewed from the data that exists between the land use map and the mining business permit, some things do not correspond even though contained in the MEMR Ministerial Decree No. 5 of 2018 about mastery of mineral and coal mining sector. Minister of Public Works Regulation No. 20 of 2007 concerning Technical Guidelines for Analysis of Physical and Environmental, Economic, and Socio-Cultural Aspects in Spatial Planning.

\subsection{Plantation Permission in sustainability area}




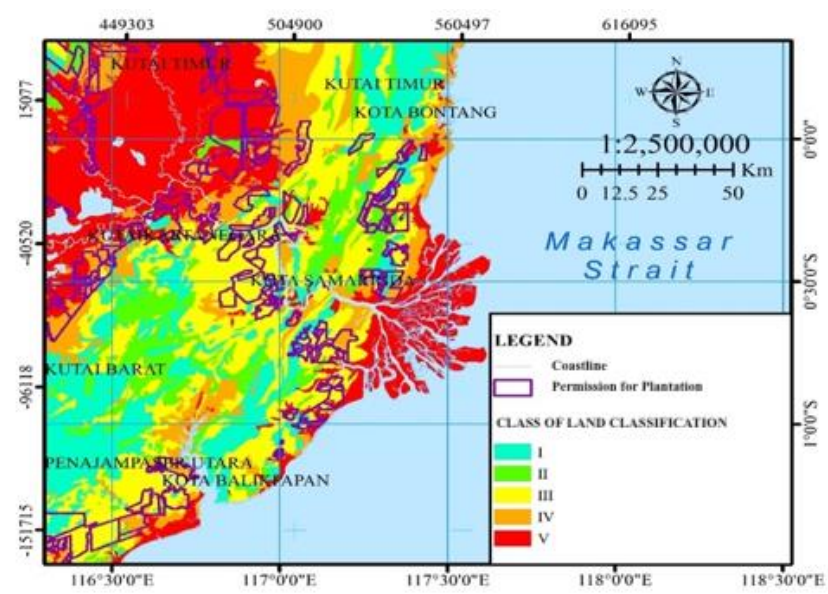

Fig. 7. Permission of Plantation in the sustainability area

Land evaluation is a tool for identifying the suitability of business patterns of land use planning over diverse land resources [2]. The most widely used physical land evaluation method is the evaluation developed by FAO (1976) to assess land suitability for certain commodities. Conformity is express descriptively using the terms: very suitable (S1), entirely appropriate (S2), marginal appropriate (S3), not suitable now (N1), or not suitable forever (N2). Land suitability analysis used in this map is the suitability of residential land. Decree of the Minister of Agriculture No.837 / KPTS / Um / 11/1981 and Keppres No. 48/1983 explain the categorization of slopes, rainfall, and soil types used for the assessment of the category of area functions and suitability of residential land.

According to Suprapto and Sunarto (1990) [6], the suitability of land for settlements is related to the conditions of the location of settlements which emphasized on the relief variables (slope, flow density, and depth of the channel), geomorphological processes (floods, erosion levels, and rock mass movements), and variables rock material (rocking, weathering level, rock strength, bearing capacity, and wrinkle development). Land suitability for settlements is generally assessed based on land characteristics that affect building foundations, comfort, sustainability, building safety, rock strength, weathering levels, soil texture, landslide hazards, flood hazards, and soil permeability.

In the map of the results of data processing, the suitability of settlement land is expressed in class I-V, which are sequentially very suitable (S1), quite suitable (S2), marginally appropriate (S3), not suitable at present (N1) or not forever (N2). Based on the results of data processing, land suitability classes I, II, and III are suitable to be used as residential land, while land suitability classes IV and V are not suitable to be used as residential land. Based on the map overlay results, it is known that the most substantial plantation business permit is in the land suitability class IV of $396,818.39$ hectares or $34.13 \%$. Then followed by land suitability class III covering $392,215.78 \mathrm{Ha}$ or $33.73 \%$, land suitability class V covering $222,853.98 \mathrm{Ha}$ or $19.17 \%$, land suitability class I covering $98,674.94 \mathrm{Ha}$ or $8.49 \%$, and land suitability class II covering 52,131.20 hectares or $4.48 \%$. 


\subsection{Permission of mining in sustainability area}

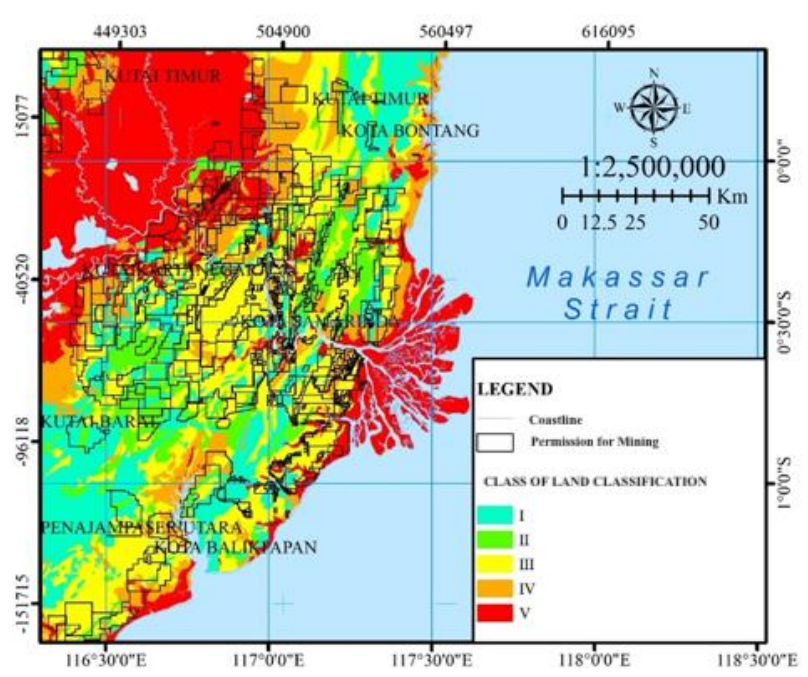

Fig. 8. Map permission of mining in the sustainability area

Based on the results of data processing, land suitability classes I, II, and III are suitable to be used as residential land, while land suitability classes IV and V are not suitable to be used as residential land. Based on the map overlay results, it is known that the most significant mining business permit is in the land suitability class III, which is $1,049,708.43 \mathrm{Ha}$ or $36.76 \%$. Then followed by land suitability class I covering an area of 774,009.30 Ha or amounting to $27.11 \%$, land suitability class IV area of $597,683.54 \mathrm{Ha}$ or amounting to $20.93 \%$, land suitability class II covering $238,357.77 \mathrm{Ha}$ or $8.35 \%$, and land suitability class V covering $195,467.89 \mathrm{Ha}$ or $6.85 \%$. Based on the data above, it can see that mining business permit materials found in or in many areas which constitute land that has a land suitability value as a residential area, namely class I and class III land. When viewed in priority, mining business permits should be focused more on class IV and V regions than should be in class I, II, and III land areas. However, it also needs to be seen from the level of damage caused by the mining process. It is unfortunate if the land suitability class I is carried out by mining activities because it will experience land degradation and will require a very long time and a high cost to return the land to normal. The mining business has a high level of damage if it not followed by the application of efforts to protect the environment of the mining area both from the premining process to the post-mining process.

\subsection{Overlap of Mining and Plantation Area}

East Kalimantan Province has a land area of 12,734,692 Ha. Some of the areas were permitted plantation and mining businesses. East Kalimantan Province plantation business permit covering $1,162,694.29$ hectares or $9.13 \%$ of the total area. East Kalimantan Province mining business permit covering an area of 2,855,226.94 hectares or $22.42 \%$ of its area. Based on the results of data processing, it known that there is an overlap between plantation and mining business permits covering an area of $449,753.53$ hectares or $3.53 \%$. From 209 plantation business licenses and 1189 mining business licenses, there are 703 overlapping 
regional permit issues. It triggers conflicts between business permit holders as an example of a plantation business permit owned by PT. Kartanegara Kumala Sakti overlaps with PT. Aditya Kirana Mandiri was covering an area of 4,464.39 Ha, as well as a plantation business permit owned by PT. Agrojaya Tirta Kencana overlaps with a mining business permit owned by PT. Trowels Energy covering an area of 3,934.05 Ha.

\subsection{Plantation permission for business in the spatial planning area}

Plantation business licenses covering 1,162,694.29 Ha or $9.13 \%$ from total land area of East Kalimantan Province as a whole spread over 209 plantation locations. Based on the plantation business permit granted, it is seen that $78.8 \%$ or an area of $916,178.83 \mathrm{Ha}$ was grant according to the plantation spatial plan. While the incompatibility of granting plantation permits lies in the plan for the pattern of the rural settlement area of 121,780.57 hectares or $10.47 \%$, this is because the closer the plantation location is to the settlement, it will make it easier for the community to manage and harvest the garden products. Furthermore, plantation business permits in Coastal Conservation Areas, Urban Settlements, Protected Forests, Grand Forest Parks, Road Buffers, Mangrove Conservation, Mining, Industrial Estates, Water Bodies, Nature Reserves, Food Crop Agriculture, Food Crop Agricultural Reserves, Geological Protected Areas (Karst), Limited Production Forest covering 46,593.61 Ha or 4.01\%, Conversion Production Forest covering 45,460.63 Ha or 3.91\%, and in Production Forest covering $32,680.67 \mathrm{Ha}$ or $2.81 \%$. The incompatibility of plantation business permits with the planned spatial patterns has become an evaluation for the government of East Kalimantan Province.

\subsection{Permission of Mining Area in Spatial Planning}

Mining business permits covering an area of 2,855,226.94 Ha or amounting to $22.42 \%$ of the total land area of East Kalimantan Province as a whole spread over 1189 mining sites in East Kalimantan Province. The use of forest areas for mining purposes is done through the granting of a lease-to-use permit by the Minister by taking into account specific area and time limits and environmental sustainability. Based on Table 4.10, it is known that the most significant mining business permit was granted in the production forest area, which is $1,022,874.24 \mathrm{Ha}$ or $35.82 \%$, followed by the plantation space pattern of $813,574.41 \mathrm{Ha}$ or $35.82 \%$ and production forest limited area of $572,978.39 \mathrm{Ha}$ or $20.07 \%$. While for figures below 5\%, mining business permits were granted in the Conversion Production Forest space pattern of 115,495.41 Ha or 4.05\%; rural settlements covering an area of 105,094.12 hectares or 3.68\%; Coastal Conservation Areas, Nature Reserves, Road Buffers, Mines, Industrial Estates, Plantation Reserves, Mangrove Conservation, National Parks, Grand Forest Parks, Water Bodies, Urban Settlements, Agricultural Plant Reserves covering an area of 105,110.79 Ha or $3.68 \%$; Protection Forest covering an area of $60,134.92 \mathrm{Ha}$ or $2.11 \%$; and Food Crop Agriculture covering an area of $59,964.66 \mathrm{Ha}$ or $2.10 \%$. Based on the comparison between mining business permits and plantation business permits with the East Kalimantan spatial pattern, several problems can consider in the future development plan:

(i) It appears that economic transformation has not yet entirely gone well. This can also be seen from the composition of East Kalimantan's GRDP in the mining sector by $43.34 \%$, followed by the manufacturing industry sector by $20.51 \%$. For Regency / City, the most significant mining sector's contribution was in East Kutai Regency with $79.23 \%$ and 
Paser with $71.31 \%$. Whereas the most significant processing industry is in the Bontang region, $83.96 \%$, and Balikpapan 47.62\%. The low value of industrialization and processing is an indication that the downstream processing has not been processed either from the mining sector or from the forestry and fisheries sectors. It shows that economic transformation has not entirely gone well.

(ii) The continued reduction in forest land caused by the conversion of forest functions to mining or mining locations results in a decrease in environmental quality. So there is a need for monitoring and data collection again on the extent of forests that still function as forest land areas in the province of East Kalimantan.

\subsection{Permission for Plantation and Mining Area in Structure Planning Area}

Plantation business licenses covering 1,162,694.29 Ha or $9.13 \%$ of the total land area of East Kalimantan Province as a whole spread over 209 plantation locations in East Kalimantan Province. There are four national centers of activity in the Province of East Kalimantan, namely in the cities of Samarinda, Bontang, Tenggarong, and Balikpapan. There are plantation business licenses issued in the region, with the Tenggarong and Samarinda city areas being the center of the political activity with the most plantation business licenses granted. There are 19 local activity centers in the East Kalimantan region, 19 local activity centers are not located in the center of the distribution of plantation business licenses, but scattered around the edges of the plantation business permit location. Mining business permits covering an area of $2,855,226.94 \mathrm{Ha}$ or amounting to $22.42 \%$ of the total land area of East Kalimantan Province as a whole spread over 1189 mining sites in East Kalimantan Province. There are four national centers of activity in the province of East Kalimantan, namely in the cities of Samarinda, Bontang, Tenggarong, and Balikpapan. There are mining business licenses issued in the region, with the Tenggarong and Samarinda municipal areas being the center of political activity with the most mining licenses granted. There are 19 local activity centers in the East Kalimantan region, 19 local activity centers are not located in the center of the distribution of mining business licenses, but scattered around the edges of the mining business permit location.

\subsection{Green Growth Compact in East Kalimantan}

The Minister of Environment and Forestry, Siti Nurbaya, on September 27, 2016, declared the Green Growth Compact (GGC) for East Kalimantan. There are three essential things related to the Green Growth Compact (GGC). The first is the context, the second relates to content, and finally, the coherence with Government policies, in this case, the Ministry of Environment and Forestry. On the context side, this GGC can inspire Indonesia from East Kalimantan. The best practices that have been carried out by East Kalimantan can make an excellent contribution to other regions in the context of green development. Meanwhile, in terms of GGC content, it certainly can encourage green economic growth such as green technology, a new engine for growth, low carbon for fossil fuel use, increase carbon sinks, and even green social forestry practices [7]. 
This GGC aims:

(i) Strengthen and expand existing initiatives

(ii) Filling existing gaps collaboratively

(iii) Integrate obligations that must be carried out with voluntary company commitments

\section{Conclusion}

Based on a comparison between mining business permits and plantation business permits with the East Kalimantan spatial pattern, it can see that the economic transformation has not fully implemented well. The low value of industrialization and processing is an indication that the downstream processing has not been processed either from the mining sector or from the forestry and fisheries sectors. The continued decline in forest land caused by the conversion of forest functions to mining or mining sites results in a decrease in environmental quality.

Green growth compact (GGC) is a framework agreement that guides the parties in developing more operational planning, performance-based policies within the regulatory framework, and the working practices of the parties to achieve common goals in support of East Kalimantan. Reduce deforestation minimum $80 \%$ by 2025 , restore the forest into best condition and increase economic growth by $8 \%$ while reducing emissions by 1,000 tons $\mathrm{CO}_{2} \mathrm{e}$ per the US \$ 1 million of GDP on 2030 is some of the centered interrelated targets of GGC concept from East Kalimantan. The GGC will show how commitment and partnerships at the local level can have a global impact.

Acknowledgements. I want grate full thanks to all friends in the School of Environmental Science class Indonesia University who have already helped and created this paper into suitable material for study. I hope the material presented in this paper can help many people in terms of sustainable development, which will later need to seen as risks, mitigation, and the process of supervision.

\section{References}

[1] BPBD Kalimantan. (2012). Province Infographic : Kalimantan Timur. Samarinda.

[2] Hardjowigeno, W \& Widiatmaka. (2007). Evaluation of Suitability and Landuse Planning. Gadjah Mada University Press. ID: Yogyakarta.

[3] Indonesian Statistics. (2018). East Kalimantan Privince in Number 2018.

[4] Luthfi Muta'ali. (2005). Potential of Regional Development and Relation between Spatial Planning in Slope Area of Merapi in Yogyakarta. Indonesian Grographic Magazine, 6388.

[5] Perda Kaltim. (2016). Capability of Development Planning In Middle Time Series for East Kalimantan Province from 2013-2018.

[6] Satria, M. and Rahayu, S. (2013). Evaluation of Suitability Land for Settlement in Semarang City East Java. Journal of Teknik PWK. 2(1): 160 - 167.

[7] Saufi, N. A. A., Daud, S., \& Hassan, H. (2016). Green Growth and Corporate Sustainability Performance. Procedia Economics and Finance, 35(December), 374-378. https://doi.org/10.1016/s2212-5671(16)00046-0 
[8] Republic of Indonesia. (2007). National Constitution Number 26 in 2007 about Spatial Planning. Jakarta: State Secretariat. 